\title{
Evaluation of Policy for Inclusive Education in Early Childhood Education Institutions in Medan City
}

\author{
Ditta Manullang \\ Education Management \\ State Uniersity of Medan \\ Medan, Indonesia \\ ditta.manullang@kemdikbud.go.id
}

\author{
Eka Daryanto \\ Education Management \\ State University of Medan \\ Medan, Indonesia
}

\author{
Zainuddin \\ Education Management \\ State University of Medan \\ Medan, Indonesia
}

\begin{abstract}
The Education Policy for the Implementation of Inclusive Education is regulated in the National Education Ministers Regulations of Indonesia No. 70 of 2009, and the North Sumatra Governor Regulation No.29 of 2016 concerning the Implementation of Inclusive Education. However, in its implementation various problems arise, namely inclusive education for special needs children is not yet understood as an effort to improve the quality of education services, teacher competence is still unable to carry out learning for special needs children , unavailability of Special Advisory Teachers in inclusive education institutions, facilities and infrastructure what is available is not in accordance with the needs of the special needs children, so that the policy needs to be evaluated. This study aims to describe and discuss the achievements and factors of failure to achieve the implementation of policies for the implementation of inclusive education in early childhood institutions in the city of Medan. This research was conducted using descriptive research methods with a qualitative approach that emphasized the study of 6 (six) research indicators from William N. Dunn (2000: 610), namely effectiveness, efficiency, adequacy, similarity, responsiveness, and accuracy. Data collection was conducted through interviews with 18 informants consisting of 2 Education Department respondents, 4 Principal respondents from inclusion early childhood education institutions in Medan city, 8 teacher respondents from inclusion early childhood education institutions in the city of Medan, and 4 parents of respondents from special needs students in inclusion early childhood education institutions in Medan, with a purposive sampling technique. The results of this study indicate that the evaluation of the implementation of inclusive education policies in early childhood education institutions has not been well implemented, there are still some obstacles : there is no Special Advisory Teacher in inclusion early childhood education institutions, inadequate facilities and infrastructure to meet the special needs of children with special needs, the response of the Medan City Education Department is still in the form of socialization of inclusive education and monitoring to early childhood education institutions. Therefore, there is a need for good coordination and collaboration between relevant agencies in the Province of North Sumatra to better implement inclusive education.
\end{abstract}

Keywords- Inclusive Education Policy; Early Childhood Education Institutions

\section{INTRODUCTION}

Inclusive education is a form of education that unites children with special needs with normal children in general to study. According to Hildegun Olsen (Tarmansyah, 2007; 82), inclusive education is a school that must accommodate all children regardless of physical, intellectual, social emotional, linguistic or other conditions. This must include children with disabilities, gifted, street children and child laborers come from remote or mobile populations. Children who come from ethnic minority, linguistic or cultural populations and children from areas or groups that are disadvantaged or marginalized.

Based on data from the Central Statistics Agency (BPS) in 2017, the number of children with special needs in Indonesia reached 1.6 million children. One of the efforts made by the Ministry of Education and Culture (Kemendikbud) to provide access to education is for them to build new school units, namely the Extraordinary School (SLB), and encourage the growth of the Inclusion School in the regions.

Of the 1.6 million children with special needs in Indonesia, only 18 percent have received inclusive education services. Around 115 thousand children with special needs attend school in SLB, while ABK who attend regular schools implementing the Inclusion School number around 299 thousand.

To provide access to education for ABK who do not attend school, the Ministry of Education and Culture has implemented the Inclusion School program. At present there are 32 thousand regular schools that become Inclusion Schools in various regions.

The next stage of inclusion education for children with special needs, the Regional Government of North Sumatra Province issued North Sumatra Governor Regulation No.29 of 2016 concerning the Implementation of Inclusive Education in North Sumatra Province

In 2015, the Director General of Teachers and Education Personnel of the Ministry of Education and Culture, Sumarna Supranata officially declared North Sumatra as the eighth province of inclusive education in Indonesia. There were 633 schools in this province, ready to accept children with special needs.

According to research of Efika Nurahmasari Lubis with the title Implementation Policy for Inclusive Education of Elementary Schools in Yogyakarta City. Research locations in several elementary schools (Inclusive Education Organizers) throughout Yogyakarta City. This study uses the theory of 
George C. Edwards III (1980), Merilee S. Grindle (1980), Daniel A. Mazmanian and Paul A. Sabatier (1983), and Van Meter and Van Horn (1975). The results of this study the implementation of the policy of implementing inclusive education in the city of Yogyakarta is good enough, seen from 5 interrelated and inseparable components, namely Bureaucratic Structure, Communication, Resources, Policy Environment, Characteristics of Problems.

Research conducted by Sasadara Wahyu Lukitasari entitled Evaluation of the Implementation of Inclusive Education Policy. The research sites of several schools that were designated as pilot projects of the inclusion program in Salatiga City at the primary education level, namely elementary and junior high schools. The theory used in this study is a systematic policy evaluation model of communication, resources, disposition, and bureaucratic structures as mentioned in the Edwards III implementation model. The results of this study that overall the implementation of the inclusion program policies are included in both categories. In terms of communication evaluation data shows that there are problems in almost all aspects of communication because four of the five aspects show poor judgment. In terms of bureaucratic structure, the implementation of inclusive education policies at the city level is managed by a Working Group (Pokja). In terms of resources, evaluation shows that overall policy implementation resources are in the good category, which is characterized by a good assessment of four of the five assessment indicators. In terms of budget, the fulfillment of the cost to run the inclusion program in Salatiga City is already good. In terms of disposition of policy implementers, the commitment of policy implementers to implement this program is considered good, although there are still perceived problems in terms of respect for policy implementers.

Based on the data and results of the above research, it can be seen that the implementation of inclusive education is a policy that was rolled out to eliminate discrimination in the field of education in order to realize the concept of education for all. But in its implementation there are still many things that need to be improved. The problems that occur in the Implementation of Inclusive Education make researchers think that have to conduct research and further evaluate the implementation of inclusive education policies. This is to see whether the implementation of the policy is appropriate and reaches its initial objectives and whether it has provided benefits to the target groups. Therefore, the researcher formulated the research title as follows: Evaluation of the Policy for Implementing Inclusive Education in Early Childhood Education Institution in Medan City.

\section{STUDY OF THEORY AND METHOD}

Badjuri and Yuwono (2005: 25) state that if the stages are quite important and often overlooked their effectiveness in the context of public policy in Indonesia is policy evaluation. The term evaluation has a very related meaning, each pointing to the application of several scale values to the results of policies and programs.
William Dunn (2000 : 608) has the opinion that evaluation of public policy has four spheres of meaning, namely evaluation of policy formulation, evaluation of policy implementation, policy performance evaluation, and evaluation of policy environment. In this study the researcher will conduct an evaluation using an implementation evaluation approach, namely evaluating inputs, processes and outputs and using appropriate policy evaluation criteria to facilitate researchers to conduct evaluations. According to William Dunn (2000: 610) there are six criteria for policy evaluation, namely :

- Effectiveness, related to technical rationality, always measured from the unit of product or service and monetary value.

- Efficiency, related to the amount of effort needed to produce a certain level of effectiveness.

- Adequacy, related to how far a level of effectiveness satisfies needs, values, or opportunities that foster problems.

- Similarity, related to legal and social rationality and refers to the distribution of consequences and effort equally among different groups in society.

- Responsiveness, related to how far a policy can satisfy people's needs, preferences or values.

- Accuracy, relating to substantive rationality, analyzing the benefits of a policy towards the target group.

According to Berns in Groce (in Kustawan and Hermawan, 2013) mentioned that inclusive schools are seen as schools that provide learning services for children with special needs to be together with normal children in the school community.

Article 1 paragraph 14 of Act No. 20 of 2003 concerning the National Education System, states : early childhood education is an effort aimed at providing guidance to children from birth to the age of six years through the provision of educational stimulation to help growth physical and spiritual development so that children have readiness in entering further education.

In this evaluation study of the Implementation of Inclusive Educatio, researchers used descriptive qualitative research. This study focused on evaluating the Policy for Implementing Inclusive Education at Early Chilhood Education Institution in Medan City. In conducting this research, the research samples that will be taken by researchers are the Medan City Education Office and several Early Chilhood Education Institution in Medan namely : Yabes's Play Group, Metro's Play Group, Pancaran Mutiara Hati's Play Group and Pelita Hati's Play Group. The selection of several institutions as a place of research is because some of these institutions have held inclusive education so far. Principals and Teachers in this institution have already participated in Training for Development Competency in Inclusive Education that organized by BP-PAUD and Dikmas which is the Ministry of Education and Culture technical implementation unit in the Province of North Sumatra. 
The researcher decided to use a sample collection technique in a non probabilty sampling method. The non probabilty sampling technique used was purposive sampling. Data collection techniques are carried out through observation, interviews, and documentation studies.

\section{RESULT AND DISCUSSION}

\section{A. Policy for Providing Inclusive Education to Early Chilhood Education Institution is evaluated based on input:}

1) Effectiveness: Head of unit and staf of early childhood education and community education at Medan City Education Office know and understand the Governor's Regulation number 29 of 2016 concerning the Implementation of Inclusive Education. As a follow-up from the Governor of North Sumatra, the Education Office of North Sumatra Province has carried out socialization on inclusive education to Principals and several Early Chilhood Education institutions in Medan.

The Principal of the institution at the research site in accordance with the North Sumatra Provincial Governor's Regulation accepts children with special needs to attend school in their institution.

2) Efficiency: Early Chilhood Education institutions use experts such as psychologists or therapists to be able to detect children with special needs. With the results of the detection carried out by Psychologists or Therapists, the teachers at the school where the research was conducted then drafted a learning program for children with special needs.

\section{B. Policy for Providing Inclusive Education to Early}

Childhood Education Institutions is evaluated based on the process :

1) Effectiveness: Early Chilhood Education institutions do not have the funds to be able to present Special Advisory Teachers to assist students with special needs. The problem of lack of funds is then overcome by discussing with parents of special needs students. The results of discussions between teachers and parents agree that parents can accompany their children during teaching and learning and play with other normal children at the school.

2) Efficiency: Early detection is carried out by Psychologists / Therapists to children with special needs. Based on the results of this detection, the teachers at the school design individual learning programs for children with special needs. Principals and Teachers have participated in Training for Development Competency in Inclusive Education organized by the Development Center for Early Childhood Education and Community Education (BP-PAUD and Dikmas) of North Sumatra Province. This training activity is very useful because increase the capacity of the Principal and Teachers in conducting learning in children with special needs, among others, help teachers to make the preparation of individual learning programs for children with special needs, train teachers make a lot of stimulations for the development of abilities of children with special needs and train teachers make learning media for children with special needs.
Early Childhood Education institutes where the research conduct, had never received Operational assistance for the implementation of inclusive education.

The socialization of student acceptance with special needs is carried out by principal of the school during the new school year through providing information to parents of students, going to the homes of citizens around the school and socializing word of mouth in the midst of the community.

Inclusive education services organized by the school are carried out by combining normal children and children with special needs in class settings. So that children with special needs can interact and socialize in learning and playing activities with their normal child friends.

The Principal and the Teachers jointly design and compile the individual learning program for children with special needs, create and develop learning media specifically for children with special needs.

3) Adequacy: Facilities and infrastructure available at the institution in general are not sufficient and appropriate to be able to provide good education services for children with special needs.

4) Leveling: The school management provides equal opportunities to normal children and children with special needs to be able to learn and play together.

5) Responsiveness: The response from the Education Office of North Sumatra Province to the policy of inclusive education in the form of socializing the implementation of Inclusion Education at Early Childhood Education Institutions and monitoring activities in the school.

6) Accuracy: Educational services have been provided for children with special needs through the preparation of the individual learning program and the creation of learning media.

\section{Policy for the Implementation of Inclusion Education in Early Childhood Education Institutions is evaluated based on output :}

1) Effective: The schools do not have the funds to be able to present Special Advisory Teachers to assist students with special needs. The problem of lack of funds is then overcome by discussing with parents of special needs students. The results of discussion between teachers and parents agree that parents can accompany their children during teaching and learning and play with other normal children

2) Efficient: The results of the learning evaluation that the teacher has made are known that the concentration ability of children with special needs has been well developed. This means that stimulation activities carried out by teachers have provided benefits for children with special needs to exercise their concentration skills.

3) Leveling: Children with special needs get the same opportunity as other normal children to get an education at the school. 
4) Adequacy: Facilities and infrastructure available at the school in general are not sufficient and appropriate to be able to provide good education services for children with special needs.

5) Responsiveness: The response of students who are normal children can accept the presence of children with special needs and can play and learn together with their friends.

6) Accuracy: School policy provides an opportunity for parents to accompany their children because the absence of a special advisory teacher is the right solution.

\section{Main Inhibiting Factors}

The main inhibiting factors for the implementation of inclusive education policies in Early Childhood Education institutions based on the evaluation results show that the absence of Special Advisory Teachers at the school that serve children with special needs is due to limited funds, so that they cannot present Special Advisory Teachers.

Because of that the class teacher must develop an individual learning program for children with special needs and provide their own time to be able to do learning in children with special needs. The role of Special Advisory Teachers is very necessary in the implementation of inclusive education in Early Childhood Education institutions.

\section{ACKNOWLEDGMENT}

This research was supported by Early Childhood Education and Community Education (BP-PAUD and Dikmas) of North Sumatra Province. We thank to Dr.Ulfa
Maria as leader in BP-PAUD and Dikmas of North Sumatra Province for sharing her wisdom with us during the course of this research.

We thank Dr. Eka Darianto for assistance with his particular technique and Prof. Dr. Zainuddin for comments that greatly improved the manuscript.

\section{REFERENCES}

[1] Badjuri\&Yuwono, 2005. Kebijakan Publik, Konsep dan Strategi. Semarang : Universitas Diponegoro

[2] Efika Nurahmasari Lubis.2016. Implementasi Kebijakan Penyelenggaraan Pendidikan Inklusif Jenjang SD Se-Kota Yogyakarta. Yogyakarta : Jurnal Kebijakan Pendidikan. Vol.5.

[3] Kustawan \& Hermawan. 2013. Model Implementasi Pendidikan Inklusif Ramah Anak. Jakarta : Luxima.

[4] Peraturan Gubernur Sumatera Utara Nomor 29 Tahun 2016 tentang Penyelenggaraan Pendidikan Inklusi

[5] Rahayu Kusuma Dewi. 2016. Studi Analisis Kebijakan. Bandung : CV Pustaka Setia.

[6] Rusdiana. 2015. Kebijakan Pendidikan dari Filosofi ke Implementasi. Bandung : CV. Pustaka Setia.

[7] Sasadara Wahyu Lukitasari, dkk. 2017. Evaluasi Implementasi Kebijakan Pendidikan Inklusi. Salatiga : Jurnal Manajemen Pendidikan. Vol.4, No.2.

[8] Sugiono. 2011. Metode Penelitian Pendekatan Kuantitatif, Kualitatif dan R\&D. Bandung : Alfabeta

[9] Tarmansyah. 2007, Inklusi Pendidikan Untuk Semua. Jakarta : Depdiknas.

[10] Undang-Undang Republik Indonesia no.20 tahun 2003 tentang Sistem Pendidikan Nasional

[11] William N.Dunn. 2000. Analisis Kebijakan Publik. Yogyakarta : Gadjah Mada University Press 